\title{
Impact of Automobile Induced Air Pollution on roadside vegetation: A Review
}

Swami, Abhishek

Department of Environmental Sciences, Shree Guru Gobind Singh Tricentenary University, Gurugram, India

Corresponding Author: abhishekswami1@gmail.com

\section{A R T I C L E I N F O}

Received: 17 January 2018 | Accepted: 22 April 2018 | Published Online: 15 August 2018

DOI: $10.31786 / 09756272.18 .9 .1 .113$

EOI: $10.11208 /$ essence.18.9.1.113

Article is an Open Access Publication.

This work is licensed under Attribution-Non Commercial 4.0 International

(https://creativecommons.org/licenses/by/4.0/)

CThe Authors (2018). Publishing Rights @ MANU-ICMANU \& ESSENCE-IJERC.

\section{A B S T R A C T}

The activities of man constitute one single factor, which often disrupt the intricate balance among the foregoing constituents of the life support system. In his eagerness to urbanize and industrialize, man has not only destroyed plant cover built up meticulously by nature over millions of years, but also polluted air, water and land, so much so that development has become synonymous with deforestation and desertification and progressed with pollution. Air pollution has become a major environmental risk as far as public health is concerned. It has been proposed that reduction in levels of air pollution may result in lessening of the global burden of disease. Emissions from vehicles possess various pollutants which cause worst form of environmental pollution. Various pollutants of vehicles altered parameters of exposed vegetation. Increase in vehicles pollution may also increase effect of vehiclesemitted pollutants on vegetation. It affects mainly the photosynthetic pigments, respiratory activities, enzymatic activities, uptake of water etc. This review highlighted on worsening air quality around the world, studies on dust interception capacity of plants, physiological alterations in plants in response to air pollution load, elemental distribution in different environmental samples and effects of urban dust particulates with respect to plant growth .

\section{K E Y W O R D S}

Road side pollution | Vehicles | Environment | Vegetation | Air pollution Tolerance Index | Automobile Pollution | Chlorophyll Content

\section{I T A T I O N}

Swami, Abhishek (2018): Impact of Automobile Induced Air Pollution on road side vegetation: A Review. ESSENCE Int. J. Env. Rehab. Conserv. IX (1): 101—116. 


\section{Introduction}

Developmental activities carry with them the seeds of environmental damage, assisted and abetted by both needs and greed of man. Activities such as manufacturing, processing, transportation and consumption not only deplete the stock of natural resources but also add stress to the environmental system by accumulating the stock of wastes. The productivity of the economic system, however, depends on the supply and quality of natural and environmental resources. While water, soil, air, forest and fisheries resources are productive assets, the pollution of water, air, atmosphere and noise are the by-products of economic development. The term pollution is derived from the Latin word 'pollutioneum' which means to defile or make dirty. According to National Environmental Research Council, "Pollution is viewed as the release of substances and energy as waste products of human activities, which result in harmful changes within the natural environment". The presence of one or more contaminant such as dust, gas, mist, odors, smoke, smog or vapors in the outdoor atmosphere, in quantity of characteristics and duration so as to be injurious to human beings, plants or animal life or to property or which unreasonably interferes with the comfortable enjoyment of life and property is known as Air Pollution. Air Pollution may be personal, occupational or community air pollution. Exposure of individual to dust, fumes, smoke, smog and gases may be regarded as personal air pollution. The type of exposure of an individual to potentially hazardous concentration of aerosols, vapors and gases in his working environment is known as occupational air pollution. Community air pollution involves pollution from a variety of sources and contaminants and factors, which cause adverse social, economic and health effects. The community air pollution not only affects many individuals but it can also exert a significant impact on man's total environment including plants, animals, buildings, property and even the wealth. Transportation is one of the most important sources of air pollution. The pollution from automobiles may be highly significant, particularly in congested and poorly ventilated roads. Congestion intensifies air pollution problems, increases commuting times, and raises vehicles operating costs. The major pollutants generated by the automobiles are hydrocarbons (HC), oxides of nitrogen (NOx), carbon monoxide (CO), smoke and lead (Trivedi and Goel 1995).

During last two decades the urban population in India has increased from 109 million in 1971 to 217.0 million in 1991 and it has increased by 1,027 million in March, 2001. With increase in urbanization and industrialization and commercial activities in the urban areas, the demand for transport has also increased considerably. The use of personal vehicles has been increasing steadily because public transport system in most of the cities is inadequate. Though, the volume of vehicular traffic in our country is not as high as compared to western countries. High concentration of pollution is created due to old age, poor performance and maintenance of most of our vehicles. Narrow roads, poor geometrics, frequent traffic jams and congestion aggravate this situation.

The use of automobiles is growing fast globally at large and with much greater pace in developing countries (Yunus et al., 1996). At global level, there were about 53 million automobiles in the 1950 s, which had exceeded to 500 million up to 2000. About 19 million vehicles are added each year to the global total (Santra, 2001).

In addition to $70 \%$ two and three wheelers, petro driven vehicles with four stroke engines constitute about $14 \%$ and disel driven vehicles are about 8 $\%$ of the total vehicles on the road. Evidently, two wheelers are the most popular and economic mode of transport. The number of two-wheelers has been growing at the rate of about $20 \%$ per year. Passenger cars and diesel vehicles are also expected to be doubled by 2010 AD. The two and three wheelers are likely to constitute $80 \%$ of the vehicles by $2010 \mathrm{AD}$ and most of these will operate in urban areas. The consumption of gasoline and diesel by the road transport sector has increased from 1.5 and 7.2 million tones, respectively in 1980 - 81 to 3.5 and 14.8 million tones in 
1995, which is approximately $1 \%$ of world fuel consumption. (Sharma and Kaur, 1997).

\section{Vehicles as a Source of Air Pollution}

About 60 to $70 \%$ of air pollution in the world is due to automobiles. Motor vehicles emit large quantities of carbon monoxide, hydrocarbons, nitrogen oxide and such toxic substance as fine particles and lead. Each of these can cause adverse effects on health and the environment. Because of the growing vehicle population and the high emission rates, serious air pollution problems have become common phenomenon in modern life. Initially, these problems were most apparent in the center of the cities but recently lakes and streams and even remote forests have experienced significant degradation as well. As more evidence of human impacts on the upper atmosphere accumulates, concerns are increasing about the fact that motor vehicles are contributing to global changes, which could alter the climate of the planet of earth. Two and three wheelers emit the highly toxic gases, in quantities that are about twice the amount emitted by other sources.

\section{Air pollutants}

Every contaminant of air cannot be called a pollutant. According to Treshow (1984) air pollutants are defined as "Arial substances that have some adverse effects on plants, animals or materials". Air pollutants are of two types:

\section{A. Particulate pollutants \\ B. Gaseous pollutants}

\section{Particulate pollutants}

Particulate pollutants may be solid or liquid particles. Larger particles such as sand and water droplets settle down quickly, while small dust particles remain suspended in the air for long time.

\section{Sources of particulate pollutants:}

Sources of particulate pollutants are air borne small, solid particles and liquid droplets e.g. dust, smoke, mist, fumes and fly ash. The sources may be either the natural processes or man made processes.

(i) Natural process: The different pollutants may be added in the air environment by any one of the following natural processes viz., Volcanic erup- tion, Blowing of dust, soil by wind, and Spraying of salt near sea coast.

(ii) Man made processes: In recent times man made processes have added more pollution in the air than the natural processes e.g. man made processes emit about 45 million tones of pollutants in the atmosphere every year. The other activities, which release pollutants in the atomosphere include, Construction - dust and asbestos particles, Power plants - fly ash, Smelters and mining fumes and Coal, wood and fuel oil combustion.

\section{Type of particulate pollutants}

Based upon their chemical nature, particulate pollutants are of two types:

(a) Inorganic particulate matter (I.P.M)

(b) Organic particulate matter (O.P.M)

\section{(a) Inorganic particulate matter:}

These are metallic oxides, sulphides and carbonates added in atmosphere when fuel containing metals are burnt, e.g. lead gasoline. Lead halides are emitted from exhaust system and condense to form particulates. Aerosol mists formed due to condensation of atmosphereic SO2.

\section{(b) Organic particulate matter:}

These are polycyclic aromatic hydrocarbonschrysene, benzo-fluranthene, benzopyrene, benzidine (carcinogenic in nature). The sources of organic particulate matter include combustion of fuels, automobiles and vegetation.

\section{Effects on plants}

Following are the different effects of air pollutants on plants:

(i). Plants are adversely affected by gaseous pollutants and deposition of particulates on soil. This deposition of toxic metals on soil makes the soil unsuitable to plant growth.

(ii). Particulates such as dust, fog, soot deposited on plant leaves block the stomata of plants, thus inhibiting the rate of transpiration.

(iii). Deposited particulates restrict the absorption of $\mathrm{CO} 2$, thereby reducing the rate of photosynthesis, thus retard the growth of plants and crop production.

(iv). Some plants are much sensitive to the traces of toxic metals, whereas particulates inhibit the action of plant enzyme system. 


\section{Gaseous pollutants}

The main gaseous pollutants are as follows:

\section{Sulphur Compounds}

Oxides of sulphur i.e. sulphur dioxide $\left(\mathrm{SO}_{2}\right)$ and sulphur trioxide $\left(\mathrm{SO}_{3}\right)$, represented as $\mathrm{SOx}$, hydrogen Sulphide (H2S), carbonyl sulphide (COS), carbon disulphide $\left(\mathrm{CS}_{2}\right)$, dimethyle sulphide $\left.\left[\mathrm{CCH}_{3}\right)_{2} \mathrm{~S}\right]$ and Sulphates $\left(\mathrm{SO}_{4}\right)$ are the most serious air pollutants. $\mathrm{SO}_{2}$ is the second most important contributor of air pollutants as it accounts for about $29 \%$ of the total weight of all pollutants. Sulphur in low concentrations is essential for animals and plants both, but it becomes injurious when its concentration increases. There are two sources of sulphur dioxide:

(1). Natural sources

(2). Anthropogenic or man made sources

Volcanoes provide about $67 \%$ of the SOx pollution, while man made sources contribute about 33 $\%$ of SOx pollution, which is mainly localized in some urban areas. Fossil fuel combustion (coal etc.) accounts for $74 \%$, industries contribute 22 $\%$ and transportation $2 \%$ of the total sulphur dioxide emission.

\section{Effects of $\mathrm{SO}_{2}$ on plants}

i. $\mathrm{SO}_{2}$ damages vegetable crops and affects plant growth and nutrient quality of plant products.

ii. Acute exposure of $\mathrm{SO}_{2}$ kills leaf tissue causing leaf necrosis.

iii. Concentration of $\mathrm{SO}_{2}$ as $1.00 \mathrm{ppm}$ is most injurious to trees causing chlorosis and dwarfing.

iv. Susceptible species like cucumber and spinach may be damaged by exposure to air containing 0.05 to $0.5 \mathrm{ppm}$ of $\mathrm{SO}_{2}$ for 8 hours. Cotton, wheat, barley and apple are most sensitive to $\mathrm{SO}_{2}$ (Trivedi and Goel, 1995).

\section{Oxides of Nitrogen}

The oxides of nitrogen involved in air pollution, denoted by $\mathrm{NOX}$, are $\mathrm{N}_{2} \mathrm{O}, \mathrm{NO}, \mathrm{NO}_{2}, \mathrm{~N}_{2} \mathrm{O}_{3}$ and $\mathrm{N}_{2} \mathrm{O}_{5}$. Of these nitric oxide (NO) is the principal compound. These oxides are largely emitted by automobiles and the electric power industry in the developed countries. In metropolitan cities, vehicular exhaust is the most important source of nitrogen oxide (NOx).

\section{Effects of NOx on Plants}

i. Higher concentration of $\mathrm{NO}_{2}$ damages the leaves of plants, retard photosynthetic activities and cause chlorosis.

ii. Vehicular exhaust consisting of about $10 \mathrm{ppm}$ of $\mathrm{NO}_{2}$ checks the metabolic activities in plant tissues.

iii. Higher levels of $\mathrm{NO}_{2}$ affect acutely the leaves of plants, retard the photosynthetic rate and cause chlorosis.

iv. Vegetative production is suppressed when the plants are exposed to $0.5 \mathrm{ppm}$ for 10 to 15 days. Sensitive plants show visible leaf injury when exposed to $5-8 \mathrm{ppm}$ of $\mathrm{NO}_{2}$ for 1 to 3 hours.

v. Plants exposed to $100 \mathrm{ppm}$ of $\mathrm{NO}_{2}$ cause leaf spotting and break down.

vi. $\mathrm{NO}_{2}$ is highly injurious to plants. Vegetative growth is suppressed when they are exposed to $0.3-0.5 \mathrm{ppm}$ for 10 to 15 days.

\section{Effect of trees on Air Quality}

Urban vegetation can directly and indirectly affect local and regional air quality by altering the urban atmosphere i.e. environment. The four main ways by which urban trees affect air quality (Nowak, 1995) are temperature reduction and other microclimatic effects, removal of air pollutants, emission of volatile organic compounds and maintenance of emissions and energy effects on buildings.

Tree transpiration and tree canopies affect air temperature, radiation absorption and heat storage, wind speed, relative humidity, turbulence, surface albedo, surface roughness etc. These changes in local meteorology can alter pollution concentration in urban areas (Nowak et al., 1998).

Trees remove gaseous air pollution primarily by uptake via leaf stomata, though some gases are removed by the plant surface. Once inside the leaf, gases diffuse into intercellular spaces and may be absorbed by water films to form acids or react with inner leaf surfaces (Smith, 1990). Trees also remove pollution by intercepting airborne particles. Some particles can be absorbed 
into the tree, though most particles that are intercepted retained on the plant surface. The intercepted particles often are resuspended to the atmosphere, washed off by rain, or dropped to the ground with leaf and twig fall. Consequently, vegetation is only a temporary retention site for many atmospheric particles.

In urban areas with $100 \%$ tree cover (i.e., continuous forest stands), short-term improvements in air quality (one hour) from pollution removal by trees were as high as $15 \%$ for ozone, $14 \%$ for sulfur dioxide, $13 \%$ for particulate matter, $8 \%$ for nitrogen dioxide, and $0.05 \%$ for carbon monoxide (Nowak et al., 2000). Emissions of volatile organic compounds (VOCs) by trees can contribute to the formation of ozone and carbon monoxide. However, in atmospheres with low nitrogen oxide concentrations (e.g., some rural environments), volatile organic carbon actually remove ozone

\begin{tabular}{|c|c|}
\hline 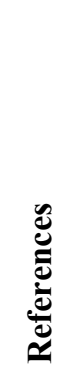 & 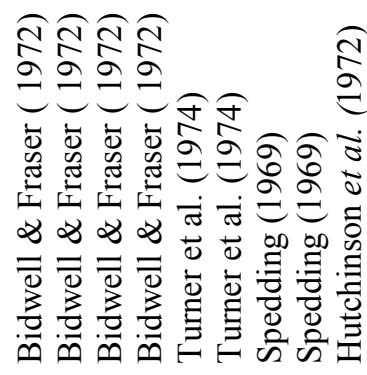 \\
\hline$\underbrace{\widehat{E}}_{>^{\infty}}$ & 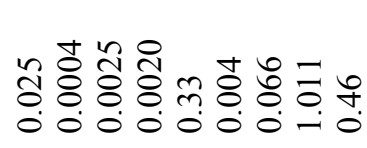 \\
\hline 参 & 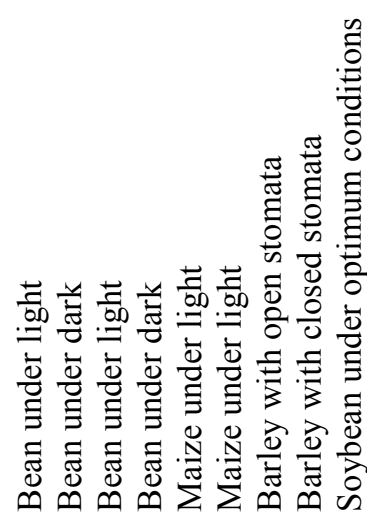 \\
\hline 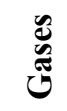 & 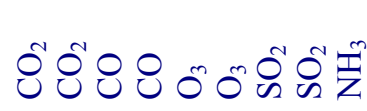 \\
\hline
\end{tabular}

(Crutzen et al., 1985). Because volatile organic carbon emissions are temperature dependent and trees generally lower air temperatures, increased tree cover can lower overall volatile organic carbon emissions and, consequently, ozone levels in urban areas (Cardelino et al., 1990).

\section{Vegetation works as pollution sink}

Vegetation offers a large surface area that acts as an important sink for the atmospheric pollutants. Plants can take-up atmospheric gases either without their active metabolism, or actively metabolizing them thus creating a concentration gradient that can facilitate their continuous absorption. While in most cases, the active metabolism of these pollutant gases results into the adverse effects on plants, it may also be beneficial in case of certain pollutants. For example, $\mathrm{SO}_{2}, \mathrm{NO}_{2}$ and $\mathrm{NH}_{3}, \mathrm{O}_{3}$ and $\mathrm{HF}$, though, readily get metabolized in the body of plants, produce several damaging effects. On the other hand, carbon dioxide, a combustion pollutant, acts as an essential ingredient of the photosynthesis, and gets incorporated in the buildings blocks of the plants. Carbon monoxide is simply absorbed by in gaseous phase.

The rate of absorption of gases by the plants is usually measured by a parameter "velocity of deposition" (Vg) represented in centimeter per second. Several works have been attempted to calculate velocities of deposition for different gases for different plants under variable conditions, the results of which is summarized Table 1.

It is evident from the data that opening of stomata under light and dark conditions has significant bearing on the absorption of gases by the plants. During the dark, the rate of absorption of gases by the plants is considerably lower than that under the light. At the time of closer of the stomata, it is only cuticle through which gases can diffuse into the leaf, but it offers usually resistance to their pollutants.

Other factors, which can determine the rate of removal of gases by the plants is the ratio of the average leaf area to the area of the vegetation canopy. It is well known that the grass like vegetation with comparatively greater leaf area per unit can- 
several gaseous pollutants like sulphur dioxide, nitrogen dioxide and ozone from the polluted air. Calculated on a 12- hour exposure basis, it has been reported that maize can absorb $0.2 \mathrm{~g} / \mathrm{m}^{2}$ of ozone; bean, $0.52 \mathrm{~g} / \mathrm{m}^{2}$ of $\mathrm{CO}$; alfalfa, $0.17 \mathrm{~g} / \mathrm{m} 2$ of $\mathrm{NO}_{2}$ and; grasslands, $0.17 \mathrm{~g} / \mathrm{m}^{2}$ of $\mathrm{SO}_{2}$ from the air having concentration typical of a polluted area (Spedding 1978).

\section{Effect of air pollution on soil}

Soil serves as an efficient medium for sink of several gaseous air pollutants. The absorption of the gases by soil can be brought about purely by chemical means or through biochemical reactions. Most of the scavenging of atmospheric pollutants takes place through precipitation and dry deposition. Soil possesses a number of organic and inorganic chemicals compounds together with sufficient moisture that can directly react with the atmospheric pollutants. For example, $\mathrm{SO}_{2}$ and $\mathrm{NO}_{2}$ can be chemically converted into sulphates and nitrates in the soil, which get incorporated later into the bodies of plants and microorganisms. Several hydrocarbons can get metabolized directly by microorganisms in the soil. Soil acts as a major sink for atmospheric carbon monoxide through soil bacteria.

\section{Effect of traffic pollution on road side plants}

The effect of environmental pollution on vegetation has been studied by Sceffer and Hedgcock (1955). Nikfield (1967) revealed that species diversity of the plant community increases with decrease in pollutant concentration. Thomas and Hill (1967) reported that short fumigation with high concentrations of sulphur dioxide caused large reduction in the photosynthetic rate of alfalfa. Pyatt (1970) and Feder (1970) have reported microscopic effects as foliar injury, appearance of chlorotic spots on leaves, flower and fruits, distortion, twisting or curling and wilting of younger leaves, stunted growth due to shortening of internodes etc. as the effect of air pollutants.

Davison and Blakemore (1976) found that gaseous form of pollutants is absorbed through the leaves, while the particulate forms are generally absorbed on the outer surface of the plant and thus less injurious to the plant. Shetty and Chaperkar (1978) used plants for monitoring of dust fall in some localities of Bombay. They have reported that leaves of Mirabilis captured dust in higher quantities as compared to some other plants, because of the presence of epidermal hairs. Leaves of trees like Erythrina, Mangifera indica, Polyalthia and Thespesia collected from Bombay environment showed that they could be used as reliable indicator of dust fall.

Furukawa et al. (1980) have found a highly significant correlation between injury and the amount of $\mathrm{SO}_{2}$ absorbed. Plants those are sensitive to $\mathrm{SO}_{2}$, absorbed greater amounts of gas than those, which are resistant to it. Because of greater absorption of labeled nitrogen dioxide by plants during the day than at night, it was suggested that the gaseous uptake was dependent on stomatal aperture (Kaji et al., 1980). Following table shows the different cases of plants growing on road side:

Das (1981) made a comparative study of the dust collecting potential of some common Indian ornamentals and avenue trees. It was noted that Ficus, Mangifera, Tectona and Polyathia are better dust collectors than Cassia, Poinciana and Sesbania. Das et al. (1981) also found that upper surface of leaves collected more dust particles than lower surface. Singh (1983) found that chlorophyll concentration and biomass of the plants at affected sites (due to $\mathrm{SO}_{2}$ ) were reduced as compared to that of control site. Viz et al. (1983) found the greater loss of photosynthetic pigments in leaves of B. retuse, M. indica, Tectona grandis, Cassia fistula and Dalbergia sissoo from healthy and polluted environment and studied foliar pigments and phenol concentration. It was found that in the leaves from polluted environment chlorophyll a, $\mathrm{b}$ and carotenoids decreased significantly, whereas the phenol content increased.

Vora and Bhatnagar (1986) have carried out comprative study of dust fall on the leaves in high pollution and low pollution areas of Ahmedabad to find out sensitive and resistant tree species to 
ESSENCE—IJERC | Abhishek, Swami (2018) | IX (1): 101-116

\begin{tabular}{|l|l|l|l|}
\hline Plant species & Source & \multicolumn{1}{|c|}{ Effect } & References \\
\hline $\begin{array}{l}\text { Populus tremula, Betula } \\
\text { pendula, Alnus glutinosa, } \\
\text { Fraxinus exselsior }\end{array}$ & Road pollution & $\begin{array}{l}\text { Stomata block and reduce diffu- } \\
\text { sion resistance of the leaf }\end{array}$ & Fluckiger et al., 1993 \\
\hline Rhododendron catabiese, & Road pollution & Increase absorption isolation & Eller et al., 1974 \\
\hline $\begin{array}{l}\text { Popular tremula, Betula } \\
\text { pendula, Acer } \\
\text { campestre, Prunus } \\
\text { avium, Quercus spp, } \\
\text { Alnus glutinosa }\end{array}$ & Road pollution & $\begin{array}{l}\text { Increase leaf temperature of the } \\
\text { leaves }\end{array}$ & Fluckiger et al., 1993 \\
\hline $\begin{array}{l}\text { Aadirachta indica, Ficus } \\
\text { religiosa, Ficus } \\
\text { benghalensis, Terminalia } \\
\text { catapa }\end{array}$ & $\begin{array}{l}\text { Road } \\
\text { pollution }\end{array}$ & $\begin{array}{l}\text { Reduce total chlorophyll, protein } \\
\text { of leaves }\end{array}$ & Wagh et al., 2006 \\
\hline Abies alba & Road pollution & $\begin{array}{l}\text { Reduce growth by Pb and No of } \\
\text { the leaves }\end{array}$ & Fluckiger et al., 1998 \\
\hline Pongamia pinnata & $\begin{array}{l}\text { The length and width of guard and } \\
\text { epidermal cells reduced }\end{array}$ & Rai and Mishra, 2013 \\
\hline
\end{tabular}

Table 2: Effects of Vehicular pollution on different cases of plants growing on road side

industrial dust pollution and Ficus religiosa, Cordiamina, Calotropis procera, Ficus drupacae were selected in both low pollution and high pollution areas. They observed very high accumulation of dust in high pollution area from automobile exhaust and residential and commercial activities in comparison to low pollution areas.

Treshow (1984) found that the interference by pollutants or varied combinations of different pollutants often lead to loss of the normal green colour of the foliage and killing of tissue were some other clearly visible expressions. Saxena (1985) reported that air pollution induced changes in foliar pigments and ascorbic acid content in Bougainvillea species. He observed significant increase in stomatal frequency and leaf area index in polluted area, but concentration of chlorophyll a, b, carotenoids and ascorbic acid were reduced.

Srivastava (1986) carried out a study to know the concentration of air pollutants in the atmosphere of Ahmedabad by taking the yearly average of minimum and maximum level of air pollutants for residential and industrial zones. He observed that the levels of $\mathrm{NO}_{2}, \mathrm{SO}_{2}$, and SPM were very high at almost all the places. He also emphasized the role of meteorology in air pollution control and concluded that the meteorology of Ahmedabad city is fairly good enough for dispersion of air pollutants. Bhatti and Iqbal (1988) have investigated the impact of the automobile exhaust on the phenology,

periodicity and productivity of some roadside trees. They have studied leaf strength, area and dry weight of four species at four sites in Karachi in 1985 to 1986, all species showed some reduction in foliage productivity on the more heavily polluted sites.

Guaiacum officinale was the worst affected followed by Ficus bengalensis, Eucalyptus and Azardirachta indica appeared to be least affected and are recommended for road side plantation. Ram (1989) studied the factors associated with black tip and internal necrosis in mango and their control and observed that black tip and girdle necrosis disorders of mango fruit occurring in northern but not in southern India are caused by gases mainly $\mathrm{SO}_{2}$, ethylene and $\mathrm{CO}$ emitted from nearby brick kilns. Incidence of black tip could be reduced by fruits with $\mathrm{NaOH}(0.6-0.8 \%)$ or $\mathrm{Na} 2 \mathrm{CO} 3$ solution to neutralize acidic gases, or by planting less susceptible cultivars such as langra. Internal fruit necrosis, taper tip and tip pulp are disorders caused not only by brick kilns gases, but by boron deficiency and could be remedied with $0.8 \%$ borax sprays. Salgare and Acharekar (1991) studied 
namely Amaranthus spinosus, Acternanthera sissilis, Ageratum conyzoids, Blumea eriantha, Cassia tora, Euphorbia hirta, Eclipta alba, Heliotropium indicum and Malachra capitata. They observed that the ambient air affected the leaf anatomy of all the studied species.

Srivastava and Rajvanshi (1991) did work on the evaluation of particulate pollution around the limestone kilns and its impact on plants. It is suggested that particulate lime deposition alters the quality and quantity of light incident on the leaf surface and thus affects chlorophyll synthesis, photosynthesis and growth. Aslam et al. (1992) carried out study on fugitive dust emissions from the stone crushers. They observed that the dust level was more at work place than that at $100 \mathrm{~m}$ distance in downward direction. Romesh et al. (1993) carried out a study of air quality at Hyderabad city for parameters $\mathrm{SO} 2, \mathrm{NO} 2$, and SPM using high volume air sampler, and discussed the results with respect to sources and possible effects.

Hussain et al. (1994) studied some road side wild trees of Peshawar city. They collected the leaves of Ficus, Zizyphus mauritiand, Prosopis glandulosa, Dalbergia sissoo and Acacia nilotica from highly polluted road side area and less polluted road side area and control. They found that leaf area of all the polluted plants were severally reduced in comparison to control and also the chlorophyll content decreased in all the polluted plant species.

Shanmughavel (1996) studied the effect of particulate pollutants on tobacco plants growing in the vicinity of sugar factory and observed that plants growing around polluted sites showed visible leaf injury symptoms like marginal necrosis, interveinal necrosis and leaf tip burns. He also recorded lower biomass value of polluted plants than that of control plants and discussed the causes of lowering of biomass.Eiler (1997) also studied the influence of road dust on the energy balance of leaves, absorption of radiation by clean and dusty leaves. Dusty leaves of Hedera helix growing near sheet with asphalt pavement absorbed $30 \%$ more radiation than cleaned leaves.
In Rhododendrom catawbinse dusty leaves absorbed $16 \%$ more radiations, while leaves covered with whitish road dust showed only $4 \%$ increase in total absorption.

Madan (1998) studied the effect of air pollution on certain tree species in Mussoorie in order to find out the air pollution tolerance index of some species. She found that higher the level of ascorbic acid in the leaves, the greater the tolerance. Out of eight species, she found that Aesculus indicus has the highest level of ascorbic acid and thus the more tolerant species.

Agarwal and Agarwal (1999) assessed the level of pollution on the roads of Dhaka city and also analyzed the effects of this on the health, on the basis of permissible limit of various pollutants and exposure time. They have also estimated the air quality index (AQI) at various locations and concluded that at more than 70 percent locations the road side air environment is severely polluted and the rest of the locations are highly polluted. They further observed that environmental condition has very serious implications on the health of inhabitants of the city, particularly commuters, causing eye and skin irritation, headache, breathing problem etc. They concluded from this study that pollution level is closely related to the density of motor vehicles playing on the roads and is expected to worsen further in the future with the increase in the number of motor vehicles caused by economic growth and industrialization. Choudhari and Gajghate (2000) reviewed the literature of the effect of air pollution on the plants and observed that many plants act as pollutant sink due to their ecological amplitude tolerance, while others are sensitive plants and exhibited morphological, anatomical and biochemical aberrations due to derogatory effects of air pollution and act as bioindicators of air pollution level. Similarly, Rawat (2001) has studied impacts of automobile pollution on some roadside plant species on Mussoorie road.

Meenambal and Akli (2000) studied the ambient air quality with respect to SPM, SO2 and $\mathrm{NO} 2$ at 10 important junctions in Coimbatore city using high volume sampler at respirable heights and 
found that the level of SPM exceed the ambient air quality standards of $\mathrm{CPCB}$ and that of $\mathrm{SO} 2$ and $\mathrm{NO} 2$ were within the limits. They have attributed the high levels of pollutants in the city to the factors like traffic congestion, increased human activities and high rise building existing parallel to each other. Bakshi (2001) studied the roadside air quality of some of the areas of Jammu city in term of suspended particulate matter (SPM) and reported higher levels of SPM at all the palaces and attributed this to the high automobile density on the roads. Raina and Sharma (2003) studied the effects of vehicular pollution on some of the parameter of leaf micromorphology, anatomy and chlorophyll contents of Syzgium cumini L. They observed that all the parameters registered decrease in their values, expected for some of the morphological and anatomical ones, at the polluted sites as compared to reference site and difference observed to be statistically significant at 0.5 level of singnificance. Raina et al. (2004) while studying the effect of vehicular exhaust on Accacia nilotica, Albizzia lebbek and Leucaena leucocephala growing along the road sides found that Albizzia lebbek was better adaptive to grow in polluted environment as compared to the other two species. Nithyamathi and Indira (2005) studied the impact of air pollution on Ceasalpinia sepiaria L. in Tuticorine city and observed a significant damage on the length of pedicle, number of flowers and seeds.

Studies on the impact of air pollution on plant response have attracted much interest. It has been shown that absorption of sulphur dioxide depends on atmospheric humidity. The presence of sulphur dioxide in the air stimulates stomatal opening or closing, both of which are regulated by relative humidity and the concentration of sulphur dioxide and $\mathrm{CO} 2$ in the air. It has also been suggested that $\mathrm{SO} 2$ injury depends on the rate of $\mathrm{SO} 2$ absorption. (Thomas 1951; Majernik and Mansfield 1970-71; Bressana et al., 1978).

Others who have carried out work on the impact of air pollutants on plants in different parts of world include Thomas 1951; Walker and
Vickeery 1961; Godzik and Piskornik 1966; Dean and Davis 1967; Majernik and Mansfield 197071; Apling et al., 1977; Ashmore et al., 1978; Black and Black 1979; Reich and Lassoie 1984; Mazurski 1986; Mansfield 1986; Mc Elwain 1988; Neighbour et al, 1988; Mott 1988; Greszta et al., 1989; Davies and Zhang, 1991; Farage et al., 1991; Beerling and Chaloner 1992; Pearson and Mansfield 1993. Air pollutants not only affect biochemical aspects of plants but also give acute injury to morphology and anatomy of plants. Some workers have reported the effects of air pollution on the morphology and anatomy of plants (Thomas 1961; Darley et al., 1963; Nivova et al., 1983; Inamdar and Chaudahri 1984; Iqbal 1985; Karenlampi 1986; Godzik and Halbwacks 1986; Krause and Dochinger 1987; Bhatti and Iqbal 1988; Gupta and Ghouse 1988; Jahan and Iqbal 1992; Wagh et al., 2006; Rani et al., 2006).

Photosynthetic pigments like chlorophyll ' $a$ ', chlorophyll ' $b$ ', and carotenoids content affected by the various air pollutants have been studied by Singh 1983; Viz et al., 1983; Abbas et al., 1991; Anbazhagan et al., 1991; Krishnamurthy et al., 1994; Garty et al., 1993; Rawat 2001 and Swami et al., 2004; Wagh et al., 2006. Tiwari and Bansal (1994) studied air pollution tolerance indices (APTI) of some planted trees in urban areas of Bhopal. APTI values of twenty five species growing in various localities in Bhopal were collected. They found that air pollution tolerance level of each plant was different and plants sharing more APTI value are more tolerant to air pollution than those having lower APTI value. Species having low APTI value may act as a bioindicator of pollution. Air pollution tolerance index is the indexes of plant tolerance capacity against air pollution, high air pollution tolerance indicates that plant have higher power to survive in polluted environment. Some workers have reported air pollution index in various plant and tree species (Agarwal et al., 1991; Kalyani and Charya 1995; Sunita and Rao 1997; Kousar et al., 1999; Mashitha and Paise 2001; Kulshreshtha et al., 2003; Ramakrishnaiah and Somashekar 2003; Swami et al., 2004). 
Dust deposited on the leaves of plant clogged the stomata and hinder the process of plant respiration. Some workers reported dust affected leaves of the vegetation due to road side automobile, thermal power plant, coal power plant and cement kilns etc. (Rao 1991; Gunamani et al., 1991; Gupta and Mishra 1994; Ignacimuthu and Muralaytaran 1994; Palaniswamy, et al., 1995; Pandey and Satya 1995; Shamnughavel 1995; Moses 1996; Urna and Rao 1996; Vijayawar and Pandey 1996; Karpate and Choudhary 1997; Pandey et al., 1999; Jha 1999; Pandey et al., 1999; Kashyap et al., 2001; Srinivas et al., 2002; Banerjee et al., 2003; Vijaywargiya and Pandey 2003).

Laboratory experiments have shown that the gaseous pollutant causes deleterious effect on physiological and biological characteristics of plants. In ambient condition, combinations of various pollutants in different proportions may cause great impact on carbon fixation and hence on yield (Heck et al., 1988). Seed of Cassia surattensis, Leucaenaleuco cephala and Parkinsonia aculeate collected from polluted area show successful decrease in growth as compare to the seeds of the plants of non-polluted area (Siddiqui and Iqbal 1994). Toxic metals are required in small quantity for plant germination. Excess concentrations of heavy metals cause reduction in metabolic activities and growth of plants. Toxic metals like cadmium cause closing of stomata, photosynthetic pigment and physiological behavior of the plant (Heckathorn et al., 2004; Kambhampati et al., 2005; Hedaya, 2008). According to Azmat et al. (2009) road traffic pollutants also affect the morphological characteristic of plants like glabrous structure (hairs). Similarly, the leaves of some plant like cauliflower, cabbage, okra, radish, spinach and brinjal are affected due to automobile discharge (Ozturk and Turkan 1993; Screbo et al., 2002; Aslan et al., 2011). Incomplete combustion of petrol release sulphur dioxide, nitrous oxide, carbon monoxides, lead and suspended particulate matter that affect the plant leaves (Rejini and Janrdhanan 1989).

Ahmad et al. (2012) stated that among the various aspects of plants, growth and morphological characteristics are effected highly when exposed to automobile released heavy metals. Cadmium show toxicity for root and shoot growth when their concentration exceeds $5 \mathrm{mg} / \mathrm{l}$. Contamination near the road side is increasing in Quetta due to rapid increase in automobile use which strongly affect morphology and physiological aspects of plants such as Vitis vinifera (Laghari et al., 2013). Road pollution affect leaves of the plant (Steubing and Fangmeier, 1989). Contamination absorbed by leaves cause reduction in chlorophyll contents which results in reduced plants productivity. Leaf surface is affected due to different trace element and gaseous discharge of automobile. Therefore road side plants are main receiver of all discharge pollutant and consequently can be effected directly by leaves.

\section{Recommendations}

It is recommended that there is a need of a proper monitoring system and to strengthen the laws of environmental protection in India to ensure the reduction of roadside pollution that affect the animals, plants but also the human population and Plants having high air pollution tolerance index should grow on air pollution stress environment by which they can reduce the air pollution level of an area, this will also help in bio monitoring works.

\section{References}

Abbas, A.; Ahmad, Malibari Z. and Saquid, M. (1991): Effect of air pollution on Ganaphalium pensylvanicum wild-A crop land weed. Geobios, 18:7-10.

Agarawal, M. and Agrawal, S. B. (1999): Impact of atmospheric pollution on plant diversity. The Botanica, 49: 38-46.

Agarwal, G. D.; Ahmed, S. and Sarmah, N. M. (1991): Some studies on ambient air quality and human health in north eastern India. J. IPHE, 4:38-48.

Anbazhagan, M. and Bhagwat, K. A. (1991): Study on the progeny of rice plant grown at an unpolluted and polluted site. Environ. Pollut, 69:17-23. 
Apling, A. J.; Sullivan, E. J.; Williams, M. L.; Ball, D. J.; Bernard, R. E.; Derwent, R. G.; Eggleto, A. E. J.; Hampton, L. and Waller, R. E. (1977): Ozone concentrations in south east England during the summer of 1976. Nature, 269:569-73.

Ashmore, M. R.; Bell, J. N. B. and Reily, C. L. (1978): A survey of ozone levels in the British Isles using indicator plants. Nature, 276:813-15.

Aslam, M.; Minocha, A. K.; Kalr, P. D. and Srivastava, R. S. (1992): Fugitive dust emission from stone crushers. Indian J. Environ. Hlth., 34(3):187-191.

Aslan, A.; Çiçek, A.; Yazici, K.; Karagoz, Y.; Turan, M.; Akku, F. and Yildirim, O. S. (2011): The assessment of lichens as bio indicator of heavy metal pollution from motor vehicles activities. African J. Agri. Res., 6:1698-1706.

Azmat, R. S.; Haider, H.; Aziz, Nasreen F. and Riaz, M. (2009): Available alternative mechanism in adapting the plants to heavy metal environment. Pak. J. Bot. 41:2729-2738.

Bakshi, N. (2001): Study on road side air quality of Jammu city. M.Sc. Dissertation, Submitted in Department of Environmental Sciences, Jammu University, Jammu.

Banerjee, S.; Singh, A. K. and Banerjee, S. K. (2003): Indian Forester., 129(8):964-977.

Beerling, D. J. and Chaloner, W. G. (1992): Stomatal density responses of Egyptian Olea europaea L. Leaves to $\mathrm{CO} 2$ change since 1327 BC. Annals of Botans., 71:431-435.

Bhati, G. H. and Iqbal, M. Z. (1988): Investigation into the effect of automobile exhaust on the pheonology, periodicity and productivity of some roadside trees. Acta Socialities Cor. Polonia., 57(3):395.

Bidwell, R. R. S. and Fraser, D. E. (1972): Can. J. Bot., 50:1435-1439.

Black, C. R. and Black, V. J. (1979): The effect of low concentration of sulphur dioxide on stomatal conductance and epidermal cell survival in field bean (Vicia faba L.). Journal of Experimental Botany., 30: 291-298.
Bressana, R. A.; Willson, L. G. and Fitner, P. (1978): Mechanism of resistance of Sulphurdioxide in cucrubitacea plant. Physiol, 61:761 $-763$.

Cardelino, C. A. and Chameides, W. L. (1990): Natural hydrocarbons, urbanization, and urban ozone. J. Geophys. Res., 95(D9):13,97113,979 .

Choudhari, P. R. and Gajghate, D. G. (2000): Assessment of air pollution effect on plants: A review. IJEP., 20 (12):926-933.

Crutzen, P. J.; Delany, A. C.; Greenberg, J.; Haagenson, P.; Heidt, L.; Lueb, R.; Pollock, W.; Seiler, W.; Wartburg, A. and Zimmerman, P. (1985): Tropospheric chemical composition measurements in Brazil during the dry season. J. Atmos. Chem., 2:233-256.

Darley, E. F.; Dugger, W. M.; Mudda, J. B.; Ordin, L.; Taylor, O. C. and Stephen, E. (1963): Plant damage by pollution derived from automobiles. Arch Environ Health., 6:700-761.

Das, T. N.; Bhaumik, A.; Ghosh, A. and Chakravarti, A. (1981): Tree as dust filters. Science Today, 15:1921.

Davies, W. J. and Zhang, J. (1991): Root signals and the regulation of growth and development of plants in drying soil. Annual Review of Plant Biology Physiology and Plant Molecular, 42: 55-76.

Davison, A.W. and Blakemore, J. (1976): Factors determining fluoride accumulation in Forage pp 17-30. In: effects of air pollutions on plant (ed. T. A. mansfield). Cambridge University press, bridge, UK: 209, Illuster.

Dean, C. E. and Davis, D. R. (1967): Ozone and soil moisture in relation to the occurrence of weather fleck on Florida cigar- wrapper tobacco in 1966. Plant Disease Report, 51:7275.

Eiler, B. M. (1997): Influences of road dust on the energy balance of leaves. Pflanzen Biology, S 1(1/2):9-11.

Eller, B. M. (1974): Road dust induced increase of leaf temperature. Environ. Pollut., 13:99107.

Farage, P. K.; Long, S. P. and Baker, N. R. 
(1991): The sequence of change within the photosynthetic apparatus of wheat following short exposure of to ozone. Plant Physiology., 95:529-535.

Feder, W. A. (1970): Environ. pollut., 1: 73-77.

Fluckiger, W. (1993): The effects of dust on vegetation a review." Environ. Pollut., 79:6375.

Fluckiger, W. and Braun, S. (1998): Nitrogen deposition in Swiss forests and its possible relevance for leaf nutrient status, parasite attacks and soil acidification. Environ. Pollut., 102:69-76.

Furukawa, A.; Isoda, O.; Iwaki, H. and Totsuka, T. (1980): Interspecific differences in resistance of SO2, Studies on the effect of air pollutants of plants and mechanisms of phytotoxicity: Res. Rep. Natl, Inst. Environ. Stud, Japan, 11:1.

Garty, J.; Karary, Y. and Harel, J. (1993): The impact of air pollution on the integrity of cell membranes and chlorophyll in the lechen Ramalina duriaei (De Not.) Bagl. Transported to industrial sites in Israel. Arch. Environ. Contam. Toxicol, 24: 455-460.

Godzik, S. and Halbwacks, G. (1986): Structural alternation of Aesculus hippocastanum leaf surface by air pollutant. Z. P. Flanzenchutz, 93:590-596.

Godzik, S. and Piskornik, Z. (1966): Transpiration of Aesculus hippocastanum L. leaves from areas of varions air pollutant. Bulletin of the Polish Academy of Sciences (series B)., 14: 181-184.

Greszta, J.; Baraszcz, J. and Neemtur, S. (1989): Evaluation of damage to montane forests in southern Poland. In: Air pollution and forest decline, ed. J. B.

Gunamani, T.; Gurusamy, R. and Swaminathan, K. (1991): Effect of cement dust pollution on the thermal appendages and anatomy of leaves in some herbaceous plants. J. Swamy Botl. Club., 8 (3 \& 4):79-85.

Gupta, A. K. and Mishra, R. M. (1994): Effect of lime klin's air pollution on some plant spe- cies. Poll. Res., 13 (1):1-9.

Gupta, M. C. and Ghouse, A. K. M. (1988): Effect of coal smoke pollutants from different sources in the growth, chlorophyll content, stem anatomy and cuticular traits of Euphorbia hirta. L. Environ Pollut., 47:221-230.

Heck, W. W.; Taylor, O. C. and Tingey, D. T. (1988): Asessement of crop loss from air pollutants. Elsevier applied sciences, London.

Heckathorn, S. A.; Mueller, J. K.; La, Guidice S.; Zhu, B.; Barrett, T.; Blair, B. and Dong, A. (2004): Chloroplast small heat-shock proteins protect photosynthesis during heavy metal stress. American J. Bot. 91:1312-1318.

Hussain, N.; Farrukh, A.; Zahir, T.; Zaman, S. and Saijque, A. R. (1994): Air borne particulate and their effect on some road side trees of Peshawar city. Sarhad Journal of Agriculture, 10(1): 85-91

Hutchinson, G. L.; Millington, R. J. and Peters, D. B. (1972): Science. 175:771-779.

Ignacimuthu, S. and Muralaytharan, V. (1994): Effect of cement kiln on dust on root tip cells of Allium cepa. J. Ecotoxico. Environ. Monit., 4(3\&4):263-265.

Inamdar, J. A. and Chaudahri, G. S. (1984): Effects of environmental pollutants of leaf epidermis and leaf architecture of Peristrophe bicalyculata. J. Plant Anat Morphol., 1:1-8.

Iqbal, M. Z. (1985): Cuticular and anatomical studies of white clover leaves from clean and air polluted areas. Poll Res., 4:59-61.

Jahan, S. and Iqbal, M. Z. (1992): Morphology and anatomical studies of leaves of different plants affected by motor vehicles exhaust. Journal of Islamic Academy of Sciences., 5 (1):21-23.

Jha, R. K. (1999): Effect of coal dust pollution on the vegetation around Dhanbad coalfield. Biojournal, 11 (1\&2):59-61.

Kaji, M.; Yoneyana, T.; Tostuka, T. and Iwaki, H. (1980): Absorption of atmostpheric NO2 by plants and soils, VI: Transformation of NO2 through the plant. In: Studies on the effects of pollutants on plant and mechanism 
of phytotoxicity: Res. Rep Notl. Envin. Stud., Japan, 11:1-8.

Kalyani, Y. and Charya, M. A. S. (1995): Biomonitoring of air pollution in Warangal city, Andhra Pradesh. Acta. Botanica Indica., 23 (1):21-24.

Kambhampati, M. S.; Begonia, G. B.; Begonia, M. F. T. and Bufford, Y. (2005): Morphological and physiological responses of Morning glory (Ipomoea lacunose L.) grown in a leadand chelate-amended soil. Int. J. Environ. Res. Pub. Hlth., 2:299-303.

Karenlampi, L. (1986): Relationship Between macroscopic symptoms of injury and cell structure changes in needle of Ponderosa pine exposed to air pollution in California (USA). Ann Bot Fenn., 23:255-264.

Karpate, R. R. and Choudhary, A. D. (1997): Effect of thermal power station's waste on wheat., J. Environ. Biol., 18 (1):1-10.

Kashyap, M. K.; Jain, A. and Banerjee, S. K. (2001): Foliar biochemical composition of some plant species growing near thermal power plant. Indian J. Environ. Sci., 5(1):1117.

Kousar, N.; Seshikala, D. and Singara, Charya M. A. (1999): Biomonitoring of air pollution by using plants in Warangal city, IJEP., 19 (7):488-492.

Krause, C. R. and Dochinger, L. S. (1987): Sulphur accumulation in red maple Acer rubrum leaves from clean and air polluted areas. Poll Res., 4:59-61.

Krishnamurthy, R.; Srinivas, T. and Bhagwat, K. A. (1994): Effect of air pollution on some bund-tree of the agriculture lands. J. Environ. Biol., 15 (2):97-106.

Kulshreshtha, A.; Dixit, C. K.; Kant, S.; Verma, V.; Kulshreshtha, A.; Jain, K. and Kumar, A. (2003): Evaluation of some air pollution tolerant plants in Agra city. IJEP., 23 (7):805808.

Laghari, S. K. and Zaidi, M. A. (2013): Effect of air pollution on leaf morphology and common plant species in Quetta city. Pak. J. Bot.
45:447-454.

Madan, S. (1998): Consequence of tourist activities on environment of Mussorie hills in the Garhwal Himalaya of U.P India. Thesis. I.C.F.R.E, F.R.I, New Forest, Dehradun, India.

Majernik, O. and Mansfield, T. A. (1970-71): Direct effect of $\mathrm{SO} 2$ pollution on the degree of opening of stomata. Nature, 227:377-8.

Majernik, O. and Mansfield, T. A. (1970-71): Direct effect of SO2 pollution on the degree of opening of stomata. Nature, 227:377-8.

Mansfield, T. A. (1986): The physiology of stomata: new insights into old problems. In: Steward, F.C. (Ed.). Plant physiology, a treatise, Vol IX. Academic Press, Orlando., 155224.

Mashita, P. M. and Pise, V. L. (2001): Biomonitoring of air pollution by correcting the pollution tolerance index of some commonly growing trees of an urban area. Poll. Res., 20 (2):195-197.

Mazurski, K. R. (1986): The destruction of forests in the Polish Sudetes Mountains by industrial emission. Forest Ecol. Mangage, 17:303-15.

Mc, Elwain and Mapson, L. W. (1958): Metabolism of ascorbic acid in Plants, Ann. Rev. Plant physiol, 119-150.

Meenamba, T. and Akli, K. (2000): Ambient air quality at selected sites in Coimbatore city. IJEP., 20(1):49-53.

Mott, K. A. (1988): Do stomata respond to CO2 concentrations other then intercellular? Plant Physiology, 86:200-203.

Neighbour, E. A.; Cottam, D. A. and Mansfield, T. A. (1988): Effect of sulphur dioxide and nitrogen dioxide on the control of water loss by birch (Betula spp.). New Phytologist., 108: 149-157.

Nickfield, H. (1967): Phytotoxicity of acidic gases and its significance in air pollution control. In: Air pollution. Springer Verlag, Berlin. 
ESSENCE_IJERC | Abhishek, Swami (2018) | IX (1): 101-116

Nithyamathi, C. P. and Indira, V. (2005): Impact of air pollution on Ceasalpinia sepiaria Linn in Tuticorin city. Indian J. Environ. and Ecoplan, 10(2):449-452.

Nivova, D. J.; Dushkova, P. I. and Kovacheva, G. V. (1983): Anatomical, morphological studies of Platanus acerifolia at various degrees of air pollution. Ekologiya (Sofia), 6:35-47.

Nowak, D. J. (1995): Tree pollute ? A "TREE" explains it all, in: Proc. 7th Natl. Urban for. Conf., (C. Kollin and M. Barrat, eds.), American Forests, Washington, DC, 28-30.

Nowak, D. J. and Crane, D. E. (2000): The Urban Forest Effects (UFORE) Model: quantifying urban forest structure and functions. In: Hansen, M. and T. Burk (Eds.) Integrated Tools for Natural smiGeneral Technical Report NC212. St. Paul, MN., 714-720.

Ozturk, M. and Turkan, I. (1993): Heavy metal accumulation by plants growing alongside the motor roads. A case study from Turkey. Plants as Biomonitors Indicators for Heavy Metals in the Terrestrial Environment. 515522. VCH Publishers, Germany Pal.

Palaniswamy, M.; Gunamani, T. and Swaminathan, K. (1995): Effect of air pollution caused by automobile exhaust gases on crop plants. Proc. Acad. Environ. Bio., 4(2):255-260.

Pandey, D. D. and Satya, N. (1995): Effect of stone crusher dust pollution on grain characteristics of maize. Env. Eco., 13 (4):901-903.

Pandey, D. D.; Nirala, A. K. and Gautam, R. R. (1999): Impact of stone crusher dust pollution on maize crops. Indian J. Env. Eco. Plan. 2 (2):43-46.

Pandey, D. D.; Nirala, A. K. and Gautam, R. R. (1999): Impact of stone crusher dust pollution on maize crops. Indian J. Env. Eco. Plan. 2 (2):43-46.

Pearson, M. and Mansfield, T. A. (1993): Interacting effects of ozone and water stress on stomata resistance of beech (Fagus sylvatica L.). New Phytologist, 123:351-358.

Pyatt, B. F. (1970): Lichens as indicator of air pollution in a steel producing town in south Wales. Environ. Pollut., 14:19-25.
Rai, P. and Mishra, R. M. (2013): Effect of urban air pollution on epidermal traits of road side tree species, Pongamiapinnata (L.) Merr. J. Environ. Scil Toxicol. Food Technol. 2: 2319 -2402 .

Raina, A. K. and Sharma, A. (2003): Effect of vehicular pollution on the leaf micro morphology, anatomy and chlorophyll contents of Syzgium cumini L. IJEP., 23(8):897-902.

Raina, A. K.; Singh, C. D.; Deepika, R. and Kumar, A. (2004): Effect of vehicular exhaust on some trees in Jammu-I. Indian J. Environ. and Ecolplan, 8(1):149-152.

Ram, S. (1989): Factors associated with black tip and internal necrosis in mango and their control. Second international symposium on Mango, Banglore, India No. 231:797-884.

Ramakrishnaiah, H. and Somasekhar, R. K. (2003): Higher plants as biomonitors of automobile pollution. Eco. Env Conserv., 9 (3):337-343.

Rao, S. (1991): Effect of cement dust pollution on plants. J. Swamy Botl. Club., 8(1\&2):35 -39.

Rawat, R. (2001): Effects of air pollution on some road side plants of Mussorie Hills. M.Sc. Dissertation, Gurukula Kangri University, Haridwar.

Reich, P. B. and Lassoie, J. P. (1984): Effects of low level O3 exposure on leaf diffusive conductance and water use efficiency in hybrid poplar. Plant Cell and Environment, 7:661 668.

Rejini, M. B. J. and Janardhanan, K. (1989): Effect of heavy metals on seed germination and early seedling growth of groundnut, sunflower and ginger. Geobios., 16:164-170.

Srikant, Romesh B. R. and Rao, M. M. (1993): Ambient NOx, SO2, and SPM levels in the industrial commercial and residential areas of Hyderabad city. Poll. Res., 12(14):239-243.

Salgare, S. A. and Acharekar, C. (1991): Effect of ambient air on the leaf anatomy of some wild plants-1. J. Env. Biol., 12(4):347-352.Santra, S. C. (2001): Environmetal science New Central Book Adency (P) Ltd. Kolkata, 301-314. 
ESSENCE—IJERC | Abhishek, Swami (2018) | IX (1): 101-116

Saxena, L. M. (1985): Air pollution induced changes in foliar pigment and ascorbic acid content in Bougainvillea spectabilis Wild and Cassia siama Linn. Acta. Ecologia., 7(1):5560.

Screbo, R.; Possenti, L.; Lampugnami, L.; Ristoni, T.; Barale, R. and Barghigiani, C. (2002): Lichen (Xanthori apariienta), biomonitoring of trace elements contamination and air quality assessment in Livorna Province (Tscany, Italy). Sci. Total Environ., 286:27-40.

Shamnughavel, P. (1995): Effect of cement dust on stomatal structure. Eco. Env. Conserv., 1 (1-4) :7-9.

Shanmughavel, P. (1996): Effect of air pollution on tobacco (Nicotiana tabacum) in agriculture fields. Eco. Env. Conserv., 2(3and4):173-174.

Shetty, R. P. and Chapekar, S. B. (1978): Some estimation on dust falls in the city of Bombay, using plants. In: Proceeding seminar on "Recent Advance in Ecology, Muzaffarnagar". Today and Tomorrow, New Delhi., 61.

Siddiqui, A. D. and Iqbal, M. Z. (1994): Growth reduction in some roadside plants. Ekologia (Bratislava), 13:155-159.

Singh, S. N. (1983): Role of foliar ureaspray in reducing pollutant injury to plant. Environmental Conservation., 10:183-186.

Smith, W. H. (1990): Air pollution and forests. New York: Springer-Verlag., 618.

Spedding, D. J. (1978): The interaction of gaseous pollutants with materials at the surface of earth. In: (Bokris, J.OM., ed.) Environmental chemistry. Plenum Press. New York.

Srinivas, N.; Chandrapaul, B. and Rao, Prasad (2002): Biomonitoring of dust pollution. Nature Env. Polln. Techno., 1(1):27-30.

Srivastava, R. S. and Rajvanshi, P. K. (1991): Evaluation of particulate pollution around the lime kilns and its impact on plants. Environ and Eco., 9:141-144.

Srivastva, J. P. (1986): SO2, NO2 and SPM in the environment of Ahmedabad. Indian J. air poll. Contl., 7(3):139-144.

Steubing, L. and Fangmeier, A. (1989): SO2 sen- sitivity of plant communities in a beach forest. Environ. J. Pollut., 44:297-306.

Sunita, M. and Madhava, Rao K. V. C. (1997): Air pollution tolerance capacities of selected plant species. J. India Bot. Soc., 76(1-2):9598.

Swami, A.; Bhatt, D. and Joshi, P. C. (2004): Effects of automobile pollution on Sal (Shorea robusta) and Rohini (Mallotus phillipinensis) at Asarori Dehradun. Him. J. Env. Zool., 18 (1):57-61.

Thomas, M. D. (1951): Gas damage to plants., Annual report on plnat physiology., 2:293.

Thomas, M. D. (1961): Effect of air pollution on plants; in Air Pollution WHO Monograph, series No. 46, (Geneva: WHO), 233-278.

Thomas, M. D. and Hill, G. R. (1967): Absorption of $\mathrm{SO} 2$ by alfalfa and its relation to leaf injury. Plant physiology., 35:291-296.

Tiwari, S. and Bansal, S. (1994): Air pollution tolerance indices of some planted trees in urban areas of Bhopal. Acta Ecol., 16(1):1-8.

Treshow, M. (1984): In: Air pollution and Plant life. John Wiley and Sons, New York.

Trivedi, R. K. and Goel, P. K. (1995): In: An introduction to air pollution. Tchnoscience Publication, Jaipur.

Turner. N. C.; Waggoner, P. E. and Rich, S. (1974): Nature, 250:486.

Urna, C. H. and Rao, R. T. V. (1996): Effect of cement dust kiln on Hibiscus cannabinus L. Geobios., 23(1):59-64.

Vijayawar, A. and Pandey, G. P. (1996): Effect of cement dust kiln on soyabean: physiology and biochemical. Eco. Env. Conserv., 2 (3\&4):143-045.

Vijaywargiya, A. and Pandey, G. P. (2003): Effect of cement dust on soyabean, Glycine max (L.) merr. and maize, zea mays Linn : in fluorescence studies. Geobios., 30(4):209212.

Viz, B. M.; Trivedi, L.; Shevade, A. and Dubey, P. S. (1983): Chlorophyll damage in tree species due to air pollution. Biol. Bull India, 3:193. 
Vora, A. B. and Bhatnagar, A. R. (1986): Comparative study of dust fall on the leaves in high pollution areas of Ahmedabad, altered praline contents of leaves. Pollen Research., 5 (3 and4):153-159.Wagh, N. D.; Shukla, P. V.; Tambe, S. B. and Ingle, S. T. (2006): Biological monitoring of roadside plants exposed to vehicular pollution in Jalgaon city. J. Environ. Biol., 37:419-421.

Wagh, N. D.; Shukla, P. V.; Tambe, S. B. and Ingle, S. T. (2006): Biological monitoring of roadside plant exposed to vehicular pollution in Jalgaon City. J. Environ. Biol., 27(2): 419:421

Walker, E. K. and Vickery, L. S. (1961): Influence of sprinkler irrigation on the incidence of weather fleck on flue-cured tobacoo in Ontario. Canadian Journal of Plant Science, 41: 281-287.

Yunus, M.; Singh, N. and Iqbal, M. (1996): Global status of air pollution: An overview in plant response to air pollution.

Yunus, M.; Singh, N. and Iqbal, M. (1996): Global status of air pollution: An overview in plant response to air pollution. Ed. M. Yunus and M. Iqbal. John Wiley and Sons., 1-34.

Sharma, B. K. and Kaur, H. (1997): Vehicular pollution. In: Environmental chemistry. Goel publishing house, Meerut.

Treshow, M. (1984): In Air pollution and Plant life. John Wiley and Sons, New York. 